\title{
Conditional gene expression systems in the transgenic rat brain
}

\author{
Kai Schönig ${ }^{1 \dagger}$, Tillmann Weber ${ }^{1,2 \dagger}$, Ariana Frömmig ${ }^{1}$, Lena Wendler ${ }^{1}$, Brigitte Pesold ${ }^{1}$, Dominik Djandji3 \\ Hermann Bujard ${ }^{4}$ and Dusan Bartsch ${ }^{1 *}$
}

\begin{abstract}
Background: Turning gene expression on and off at will is one of the most powerful tools for the study of gene function in vivo. While several conditional systems were successful in invertebrates, in mice the Cre/loxP recombination system and the tet-controlled transcription activation system are predominant. Both expression systems allow for spatial and temporal control of gene activities, and, in the case of tet regulation, even for the reversible activation/inactivation of gene expression. Although the rat is the principal experimental model in biomedical research, in particular in studies of neuroscience, conditional rat transgenic systems are exceptionally rare in this species.

Results: We addressed this lack of technology, and established and thoroughly characterized CreERT2 and tTA transgenic rats with forebrain-specific transgene expression, controlled by the CaMKII alpha promoter. In addition, we developed new universal rat reporter lines for both transcription control systems and established inducible and efficient reporter gene expression in forebrain neurons.
\end{abstract}

Conclusions: We demonstrate that conditional genetic manipulations in the rat brain are both feasible and practicable and outline advantages and limitations of the Tet and Cre/loxP system in the rat brain.

Keywords: CaMKIla, conditional expression, Cre/loxP, rat model, Tet system, transgenic rat, tTA

\section{Background}

The genetic manipulation of target genes in transgenic animals in vivo is one of the most valuable tools for assessing gene functions and for modelling human diseases. The most popular approaches for the generation of genetically modified mice are the targeted engineering of genomic DNA in embryonic stem cells to introduce gene knockouts and the DNA microinjection into the pronuclei of fertilized eggs, which results in random integration of the transgene into the genome for the overexpression of gene products.

These valuable techniques have inherent limitations related to the irreversibility and ubiquity of the germ line genetic modifications. If essential genes are targeted, this will potentially lead to embryonic lethality or activation of

\footnotetext{
* Correspondence: dusan.bartsch@zi-mannheim.de

+ Contributed equally

'Department of Molecular Biology, Central Institute of Mental Health and Heidelberg University, Medical Faculty Mannheim, J5, 68159 Mannheim, Germany

Full list of author information is available at the end of the article
}

compensatory mechanisms, which complicates or even impedes the phenotypic analyses of these animal models [1]. In particular this holds true for the large number of genes involved in the formation of neuronal structures emerging late in embryonic development or at early postnatal stages. To overcome these limitations, several techniques for the spatial and temporal control of gene expression in genetically modified mice have been proposed and developed [2], of which the Cre/loxP recombination system [3] and the tet-controlled transcription activation system (Tet system [4]) have become the most widely applied and characterized [1].

Cre is a site-specific recombinase that catalyses recombination between its recognition sites, loxP, leading to an inversion or deletion of a loxP-flanked DNA sequence. Hence, Cre recombinase can be applied to delete genes or to activate transcription by removing a transcriptional termination (STOP) sequence [1]. To obtain an inducible version of Cre, the recombinase was fused to a mutant form of the human oestrogen receptor, leading to cytoplasmic
C Biomed Central

(C) 2012 Schönig et al; licensee BioMed Central Ltd. This is an Open Access article distributed under the terms of the Creative Commons Attribution License (http://creativecommons.org/licenses/by/2.0), which permits unrestricted use, distribution, and reproduction in any medium, provided the original work is properly cited. 
localization and therefore inactivation of the fusion protein (CreERT2) [5]. Once the ligand tamoxifen is applied, CreERT2 translocates into the nucleus, where recombination takes place.

The Tet system is based on two central elements, the tetracycline (tet)-controlled transactivator (tTA) and a specific responsive promoter (Ptet), which controls expression of the transgene [4]. Ptet is specifically activated by binding of tTA. Tet and tet derivatives such as doxycycline hydrochloride (Dox) interfere with the DNA-binding activity of tTA, thereby abolishing transcriptional activation of Ptet. By tissue-specific expression of Cre recombinase or tTA, the impact of transgenic perturbation can be limited to defined cell populations.

For many scientific questions the rat is the preferential animal model [6]. This is mainly related to its larger body size, relevance to human physiology and large body of experimental experience with these animals [7]. Rats are of particular importance in neuroscience because they are the preferred species for behavioural testing of higher cognitive functions, multielectrode recordings, studies of neuronal regeneration [8] and for gene therapy experiments [9].

Up to now, the establishment of techniques for the conditional manipulation of genes in the rat is far behind those for mice [10]. Furthermore, in light of the recent technological breakthroughs that allow targeted genomic manipulations in rats, including the application of zinc finger or transcription activator-like effector nucleases [11-13] and the development of germ linecompetent rat embryonic stem cells $[14,15]$, there is an urgent need to introduce conditional technologies for rats and to develop specific Cre driver lines to realize tissue-specific genetic modifications.

In this report, we describe the generation of transgenic rat lines expressing tTA and the tamoxifen-inducible Cre recombinase CreERT2 under the control of the forebrainspecific $\mathrm{Ca}^{2+} /$ calmodulin-dependent protein kinase IIa (CaMKII $\alpha$ ) promoter. For functional characterization of the CaMKII $\alpha$-tTA and CaMKII $\alpha$-CreERT2 lines, we generated novel tTA and Cre reporter lines that allow faithful monitoring of spatial and temporal Ptet-controlled and Cre/loxP-mediated gene regulation. These novel tTA and CreERT2 lines can be used for inducible transgene overexpression, as exemplified herein with reporter genes, or for inducible gene knockouts once loxP-flanked gene alleles become available for the rat genome.

\section{Results and discussion}

Inducible gene expression in rats using the Tet system

To establish the tet-controlled conditional gene expression system in transgenic rats (Figure 1A), we generated two separate Sprague-Dawley (SD) rat strains either carrying the tTA expression unit (referred to as driver line) or the gene of interest under control of the tet-inducible promoter Ptet (referred to as response line). Double transgenic rats were generated by breeding the response lines with driver lines, generating animals heterozygous for both transgenic alleles. Such animals will express the transgene depending on administration of the tet derivative Dox, which can be supplied in the drinking water.

\section{Generation of CaMKII $\alpha$-tTA rat lines}

In mice, an $8.5 \mathrm{~kb}$ CaMKII $\alpha$ 5' regulatory sequence has been shown to efficiently drive transgenic tTA expression in excitatory forebrain neurons [16]. The resulting mouse line ( $\mathrm{Tg}$ (Camk2a-tTA)1Mmay) is one of the most frequently used transactivator mouse lines generated so far and its application has been a seminal contribution to the field of learning and memory [17]. A similar transgenic rat line would enable and facilitate the study of more complex cognitive tasks. As a similar well-characterized rat promoter fragment was not available and the cross-species use of promoters to express tet controlled transactivators between rats and mice has been successful in the past [18-20], we decided to use the functionally proven mouse CaMKII $\alpha$ promoter to spatially control tTA expression in transgenic rats (Figure 1A). After DNA microinjection, nine transgenic CaMKII $\alpha$-tTA founders could be identified, three of which transmitted the transgene to the F1 generation (lines 4.5, 4.7 and 5.1).

\section{Generation of Ptet-controlled rat reporter lines}

For functional characterization of CaMKII $\alpha$-tTA driver lines, we generated response lines carrying the reporter genes luciferase $(l u c)$ and enhanced green fluorescent protein $(E G F P)$ under the control of the bidirectional tet-inducible promoter (Ptetbi, [21]) (EGFP-Ptetbi-luc line; Figure 1A). The experimental strategy for creating the EGFP-Ptetbi-luc lines has previously been described [22]. In brief, a $75 \mathrm{~kb}$ genomic mouse fragment containing the Ptetbi-controlled transcription unit was used for microinjection into fertilized SD rat oocytes. In mice, these genomic sequences have been shown to minimize the influence of the genomic integration site on tetregulated promoters $[22,23]$. Two transgenic founders harbouring the full-length transgene could be identified. Both lines showed broad range Dox-dependent Ptetcontrolled regulation of luciferase in primary fibroblast cultures after transfection with tTA-encoding plasmids (data not shown). Therefore, both lines were used to establish independent reporter lines (EGFP-Ptetbi-luc 66.1 and 71.1).

\section{Analysis of tet-regulated gene expression in double transgenic CaMKIlo-tTA/EGFP-Ptetbi-luc rats}

All three transgenic CaMKII $\alpha$-tTA driver lines were crossed to the response lines to generate double transgenic CaMKII $\alpha$-tTA/EGFP-Ptetbi-luc rats. In these rats, preliminary luciferase luminescence analysis of crude forebrain lysates demonstrated functional Ptet-controlled luciferase expression in two CaMKII $\alpha$-tTA driver 


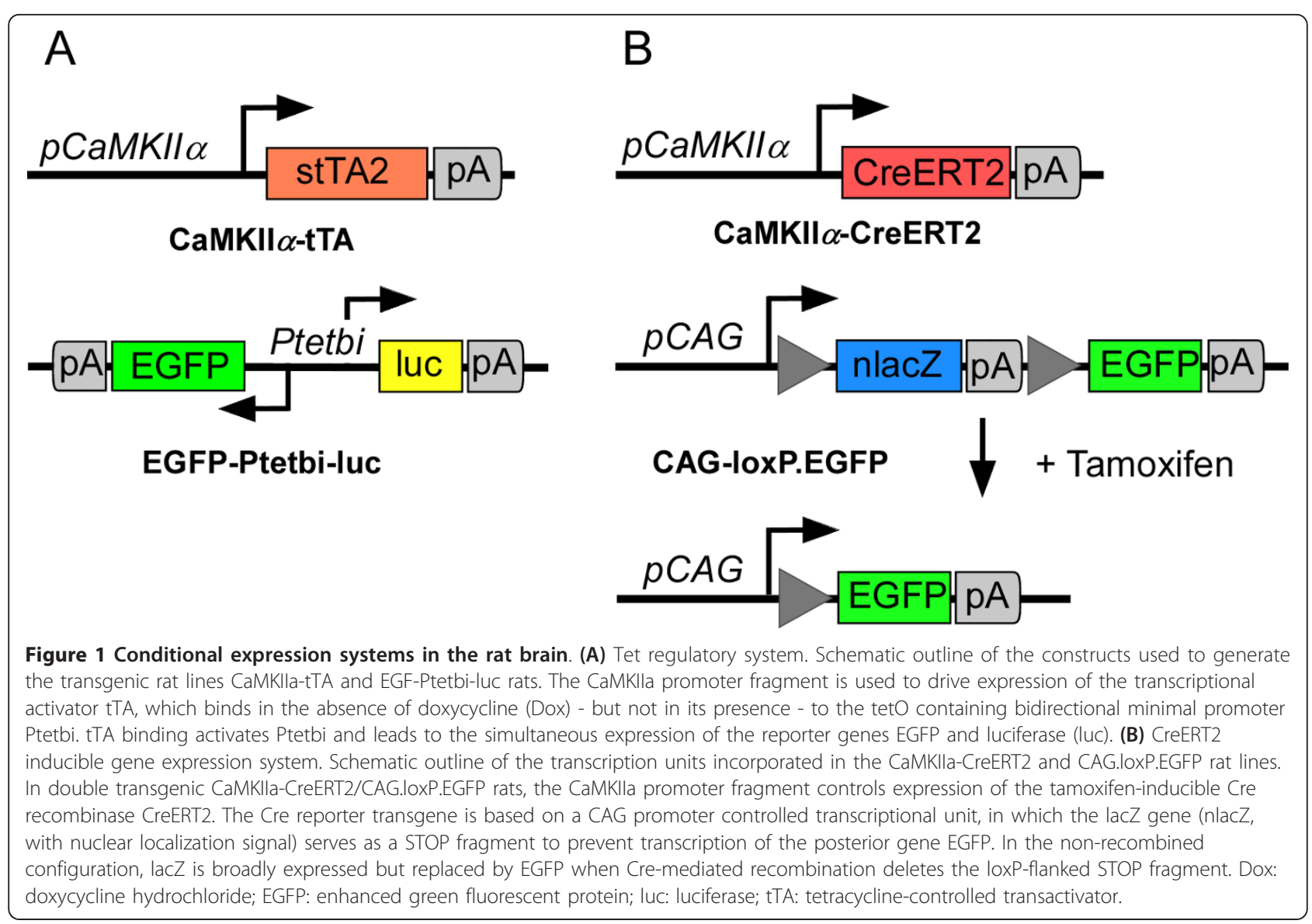

lines (lines 4.5 and 4.7). These were further used for indepth analysis of Ptet-controlled gene expression.

Transgenic animals of both tTA driver lines were mated with both EGFP-Ptetbi-luc response lines (66.1 and 71.1) to yield double transgenic CaMKII $\alpha$-tTA/EGFP-Ptetbi-luc offspring of all four combinations. Individual animals were first studied by non-invasive luciferase imaging [24] to investigate the overall distribution of Ptet-controlled reporter gene expression (Figure 2A). For that purpose, rats were injected intraperitoneally with the luciferase substrate D-luciferin and luciferase activity was monitored noninvasively in anesthetized animals using a photon imaging system [25]. As expected, brain-specific luciferase bioluminescence could be detected only over the head region of CaMKII $\alpha$-tTA/EGFP-Ptetbi-luc rats. The observed brain-specific transgenic expression was further confirmed by luciferase measurements in tissue lysates of liver, kidney, heart, lung, spleen and muscle where the enzyme activity did not exceed 1 relative light units

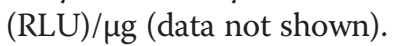

To investigate the spatial and quantitative expression pattern in the brain, we prepared tissue lysates of the olfactory bulb, cortex, hippocampus and cerebellum from double transgenic and single transgenic animals and measured luciferase activity (Figure 2B,C). All four strain combinations showed comparably high expression levels in forebrain regions while single transgenic reporter rats of line 66.1 or 71.1 showed practically no luciferase activity, confirming that Ptet-controlled luciferase expression is dependent on tTA-mediated promoter activation.

According to the endogenous CaMKII $\alpha$ expression pattern, high luciferase activity was found in forebrain regions, that is, in the olfactory bulb, hippocampus and cortex, whereas very low enzyme activity was found in the cerebellum. When luciferase reporter expression was analysed for both reporters (Figure 2B,C), CaMKII $\alpha$-tTA line 4.5 showed better expression levels in the olfactory bulb compared with line 4.7 (66.1: $P \leq 0.01$; 71.1: $P \leq$ $0.05)$, whereas luciferase activity in the other regions was comparable. No statistically significant differences were found between the two EGFP-Ptetbi-luc lines used, confirming that both rat lines show equal efficacy in reporting Ptet-controlled gene activation. However, the mean of luciferase expression was slightly higher in the cortex and hippocampus of combination 4.5. $\times 66.1$ compared with all other combinations (Figure 2B,C). As a consequence, we decided to further investigate 
A

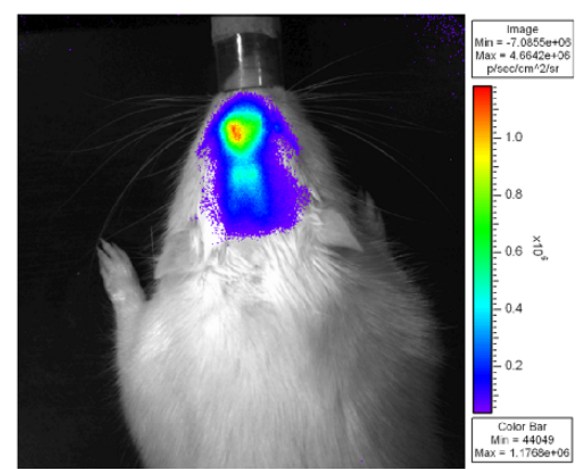

B

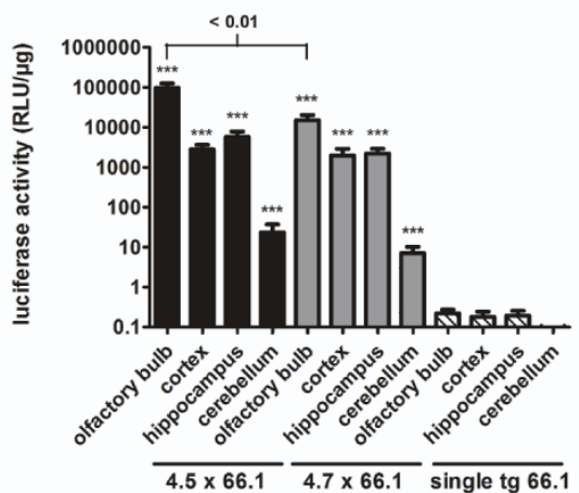

C

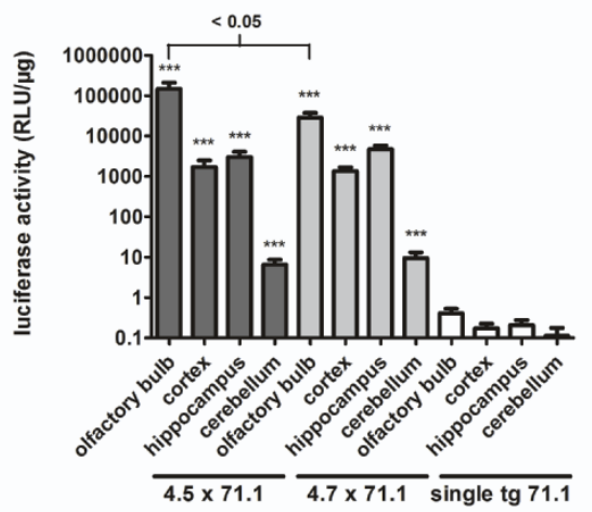

Figure 2 Luciferase expression in double transgenic CaMKIl $\boldsymbol{\alpha}$-tTA/EGFP-Ptetbi-luc rats. (A) In vivo imaging of luciferase gene activity. Representative example of brain bioluminescence after injection of the luciferase substrate D-luciferin. The rats were anaesthetized during the imaging process using $2.5 \%$ isoflurane. Shortly before the measurement, the fur was shaved on top of the head to facilitate the external detection of internally generated photons. Luciferase bioluminescence was restricted to the head region, which demonstrates brain-specific expression in CaMKIl $\boldsymbol{\alpha}$-tTA/EGFP-Ptetbi-luc rats. Photons were scattered by the skull. (B,C) Quantification of luciferase activity in different brain regions. Animals of the CaMKIl $\alpha$-tTA lines 4.5 and 4.7 were crossed to the reporter lines EGFP-Ptetbi-luc 66.1 (B) and 71.1 (C), respectively, to obtain double transgenic animals of all four combinations. Luciferase activity in lysates of double transgenic and single transgenic rats (line 66.1 and 71.1) is reported as relative light units (RLU) per $\mu \mathrm{g}$ protein and presented on a log scale. Luciferase activity conveyed by both CaMKIl $\alpha-\mathrm{tTA}$ lines 4.5 and 4.7 in combination with the Ptet-reporter 66.1 (B) was significantly higher $(P<0.001$ for all measured brain regions) than single transgenic reporter activity (olfactory bulb: $F(2,15)=304, P \leq 0.001$; cortex: $F(2,14)=118, P \leq 0.001$; hippocampus: $F(2,14)=184, P \leq 0.001$; cerebellum: $F(2,14)=37.3, P \leq 0.001)$. Identical highly significant results $(P<0.001$ for all subregions versus single transgenic reporter rats of line 71.1) were also found for both tTA driver lines in combination with line EGFP-Ptetbi-luc 71.1 (olfactory bulb: $F(2,17)=174, P \leq 0.001$; cortex: $F$ $(2,17)=155, P \leq 0.001$; hippocampus: $F(2,16)=205, P \leq 0.001$; cerebellum: $F(2,16)=28.3, P \leq 0.001)(C)$. When the luciferase activity mediated by the two transgenic tTA driver lines was compared between the two, line 4.5 showed a significantly stronger luciferase activity in the olfactory bulb $(\mathrm{dF}=12, P \leq 0.01$ in combination with reporter 66.1 in $(B)$; $\mathrm{dF}=13, P \leq 0.05$ with reporter 71.1 in (C)), whereas no significant differences were found in the other brain regions (B,C). Moreover, luciferase activity of Ptet-reporter lines 66.1 and 71.1 with both tTA driver lines (4.5/66.1 versus $4.5 / 77.1$ and $4.7 / 66.1$ versus $4.7 / 71.1$ ) was not significantly different $(B, C)$. All data are presented as mean values + standard error of the mean. Logarithmic data transformation was performed prior to statistical analysis. Stars represent $P$-values obtained by one-way analysis of variance followed by Bonferroni post hoc test: ${ }^{* *} P<0.001$. RLU: relative light units; tTA: tetracycline-controlled transactivator 
Ptet-controlled gene expression using double transgenic animals of strain combination 4.5. $\times$ 66.1.

Ptet-controlled gene expression in CaMKII $\alpha$-tTA/ EGFP-Ptetbi-luc rats was further examined on brain slices, taking advantage of the second Ptet-controlled reporter gene EGFP. EGFP was either detected by immunohistochemistry (IHC) using a GFP antibody (Figure 3A-F,H,I) or directly by fluorescent microscopy (Figure 3J). EGFP expression was restricted to the forebrain, with strong EGFP-positive cells in the olfactory bulb (glomerular layer), the cortical somatomotor and visual areas and the hippocampal CA1 to CA3 region (pyramidal layer) (Figure 3A-C). Dual-label fluorescence IHC detecting EGFP and the neuronal marker NeuN confirmed neuronal cell specificity of mosaic EGFP expression in CaMKII $\alpha$-tTA/ EGFP-Ptetbi-luc rats (Figure 3G-I). Ptet-mediated gene expression was most prominent in the hippocampus, with EGFP expression in $58.9 \%( \pm 8.9 \%, \mathrm{n}=4)$ of NeuN-positive cells in the pyramidal layer of the CA1 region; $42.8 \%$ $( \pm 6.5 \%, \mathrm{n}=3$ ) GFP-positive/NeuN-positive cells in the CA3; and $46.2 \%( \pm 5.9 \%, n=4)$ in the hilus of the dentate gyrus. In the cortex, EGFP expression was highly variable. However, in regions with notable reporter gene expression, such as the somatomotor area (layer 5), up to $38.4 \%$ $( \pm 6.9 \%, n=4)$ of NeuN cells stained positive for GFP.

The possibility to directly visualize EGFP-expressing cells indicates a very strong expression using the Tet system in these transgenic rats (Figure 3J). Luciferase and EGFP are expressed in the same brain areas, which confirms the feasibility of co-expressing two genes at the same time in rats using the bidirectional tet-promoter Ptetbi [21]. For the most part, the expression pattern found in CaMKII $\alpha$-tTA rats mirrors the spatial expression pattern found in CaMKII $\alpha$-tTA transgenic mice harbouring a similar CaMKII $\alpha$-tTA construct (olfactory bulb, cortex, striatum and hippocampus) [16,26,27]. However, only scarce expression was found in the dentate gyrus of the hippocampus and in the striatum, and expression in the cortex was highly mosaic. Endogenous CaMKII $\alpha$ immunoreactivity is detected in most, if not all, neurons in the forebrain, but not in glial cells [12]. The mouse CaMKII $\alpha$ promoter might therefore not have the full expression range in transgenic rats. However, for transgenic mice, it has been repeatedly shown that different Ptet transgenes yield varying patterns of expression in combination with the same CaMKII $\alpha$-tTA transgene $[16,27,28]$ and these differences are considered to result from integration sitedependent effects on the expression of the Ptet promoter $[29,30]$. We believe that similar mechanisms in the rat genome could act on the CaMKII $\alpha$-tTA transgene as well, leading to the mosaic-like expression pattern.

\section{Doxycycline-mediated control of gene expression}

Next, we assessed whether Ptet-controlled gene expression could be suppressed with Dox. To that end, we analysed adult double transgenic CaMKII $\alpha$-tTA/EGFP-Ptetbi-luc rats which had chronically received Dox (+Dox) during embryonic and postnatal development until postnatal day (P) $60(1 \mathrm{mg} / \mathrm{mL})$. IHC for EGFP (Figure 3D-F) demonstrated that Ptet-controlled reporter gene expression could be completely suppressed with Dox. These results were confirmed by luciferase measurements in brain extracts of the aforementioned brain regions (Figure $3 \mathrm{~K}$ ). In addition, we show that luciferase activity in adult CaMKII $\alpha$-tTA/ EGFP-Ptetbi-luc rats, which previously had not received Dox, could be efficiently suppressed by Dox treatment (+Dox adult) when given only during a short period during adulthood (P90 to P110) (Figure 3L). Dox treatment led to a 1000-fold reduction in luciferase expression in all forebrain-specific regions when compared with untreated animals (-Dox). These findings confirm that Ptet-controlled gene expression can be suppressed at any time during the rat's life.

If expression of the gene of interest is thought to be detrimental during development or if adaptive changes during development caused by the transgenic overexpression should be avoided, gene expression should be induced only after embryonic development. Hence, we determined whether Ptet-controlled gene expression could be activated when it was previously shut off with Dox $( \pm$ Dox $)$ for a period of continuous suppression during development. Dox was permanently administered to double transgenic rats during development $(10 \mu \mathrm{g} / \mathrm{mL})$ either until embryonic day (E) 18, P0 or P10, after which Dox was removed from the drinking water. Brain tissue was prepared from double transgenic offspring at P60 for luciferase quantification and IHC analyses (Figure 4). Interestingly, we found an inverse correlation between the length of Dox treatment during development and the efficiency of Ptetcontrolled reporter gene expression after Dox withdrawal. Rats treated with Dox until E18 were found to exhibit superior induction of reporter gene activity compared with rats that were treated until P0 or P10 (Figure 4A). However, even in rats treated with Dox until E18 only, the expression level did not fully reach the activation level of untreated animals (-Dox, Figure 4A). GFP antibody staining of rats treated with Dox until E18 revealed inducible gene expression mainly in the olfactory bulb (glomerular layer), the CA1 and CA3 region of the hippocampus and areas of the somatomotor cortex (Figure 4B-D). Rats treated with Dox until P0 and P10 only showed gene activation in the olfactory bulb, the CA3 region and in few cells of the cortex (Figure 4E-J). Previously, a similar weak induction has also been observed in CaMKII $\alpha$-tTA mice that were raised with Dox until P0 [26] or P21 [31]. Failure to reach full expression has either been attributed to a Dox clearance problem or to specific epigenetic modifications of the Ptet-promoter sequences in CaMKII $\alpha$-positive neurons during the suppression period [26,32,33]. 

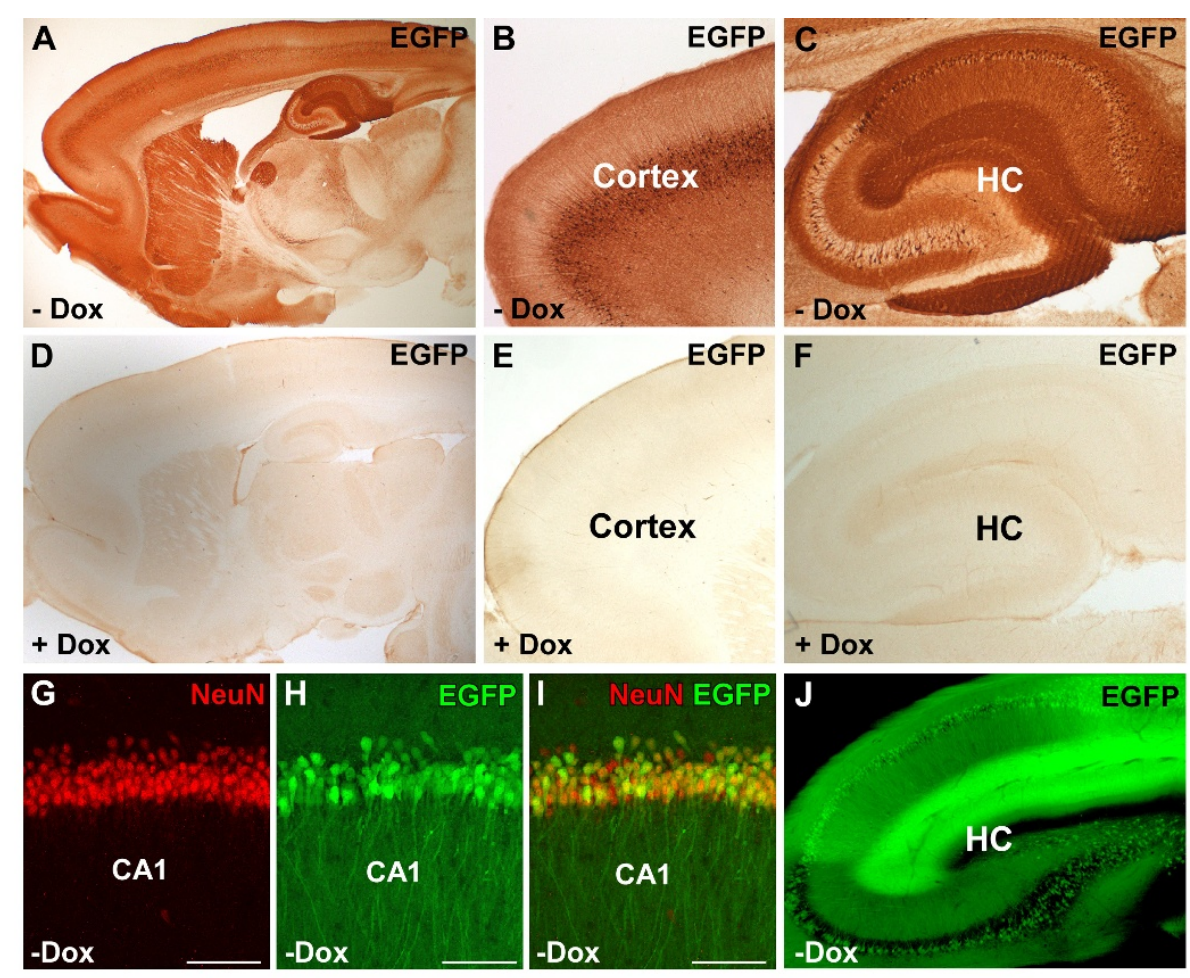

K

$\mathbf{L}$
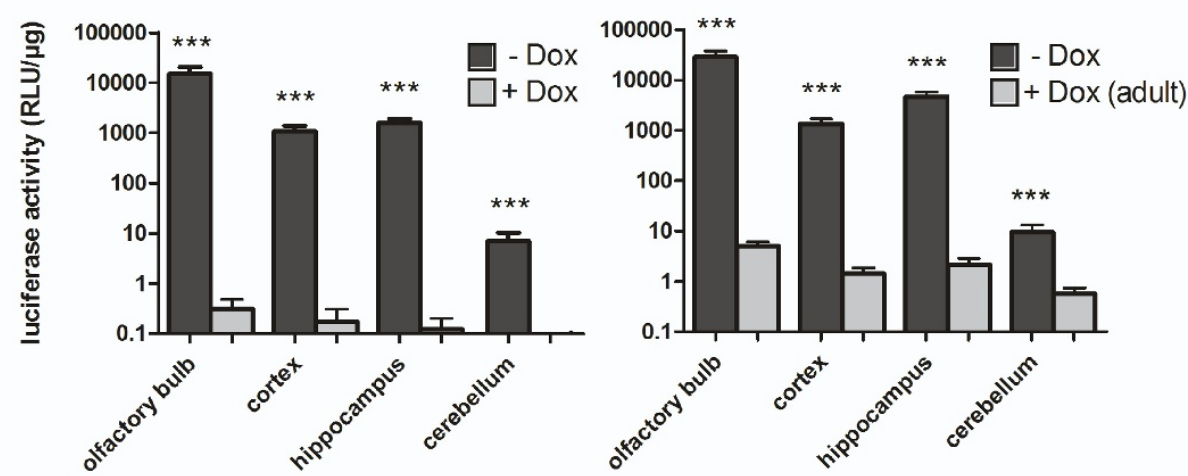

Figure 3 Doxycycline-mediated gene regulation in double transgenic CaMKIl $\alpha$-tTA/EGFP-Ptetbi-Luc rats. (A-F) Doxycycline-controlled EGFP expression in double transgenic CaMKIl $\alpha$-tTA/EGFP-Ptetbi-luc rats was visualized by immunohistochemistry on sagittal sections using an antibody against EGFP. (A-C) In the absence of Dox, strong but mosaic EGFP expression is found in the cortex and hippocampus (HC). (D-F) In adult rats, EGFP expression could be completely inhibited by chronic Dox treatment ( $1 \mathrm{mg} / \mathrm{mL}$ drinking water) from conception until analyses. (G-I) Dual-label fluorescent immunohistochemistry of brain slices with the neuronal marker NeuN and EGFP. (I) Co-localization of EGFP and NeuN was frequently found in the CA1 region of the HC indicating Ptet-controlled reporter gene expression in the absence of Dox. (J) CaMKllapromoter controlled tTA activity was directly visualized by EGFP fluorescence on sagittal brain sections of double transgenic CaMKIl $\alpha$-tTA/EGFPPtetbi-Luc rats in the HC. Strong expression is mainly found in neurons of the CA1 and CA3 region. $\mathbf{K}(\mathbf{L} \mathbf{L})$ Level of luciferase activity in different brain regions in the absence (-Dox, black) and presence of Dox (+Dox, $1 \mathrm{mg} / \mathrm{mL}$, lightly shaded). The measured double transgenic animals were obtained by crossing the CaMKIl $\alpha$-tTA line 4.5 to the EGFP-Ptetbi-luc 66.1 reporter line. (K) Animals were treated with Dox from conception throughout life until the day of analyses at the age of two months (+Dox, $n=5)$. Untreated control animals were measured at the same age (-Dox, $\mathrm{n}=8$ ). In Dox-treated CaMKIl $\boldsymbol{\alpha}$-tTA/EGFP-Ptetbi-luc rats, virtually no luciferase activity could be detected, while strong luciferase activity was found in all forebrain-specific regions (cortex, HC, olfactory bulb) of untreated rats (-Dox), leading to a highly significant difference between Dox-treated and untreated rats (*** $P \leq 0.001)$. (L) To assess whether reporter gene expression could be suppressed with Dox in adult rats (+Dox adult), double transgenic animals, which had previously not received Dox, were treated with Dox for a period of three weeks during adulthood (-Dox, $n=10,+$ Dox adult, $n=6$ ). Administration of Dox during adulthood suppressed luciferase activity, leading to a significant difference compared to untreated rats $\left.{ }^{* * *} P \leq 0.001\right)$. All data are presented as mean values + standard error of the mean. Logarithmic data transformation was performed prior to statistical analysis. Stars represent $P$-values obtained by unpaired t-test. ${ }^{* * *} P \leq 0.001$. Light units are normalized to the protein content of the lysates. Scale bar: $100 \mu \mathrm{m}$. Dox: doxycycline hydrochloride; EGFP: enhanced green fluorescent protein; HC: hippocampus. 
A
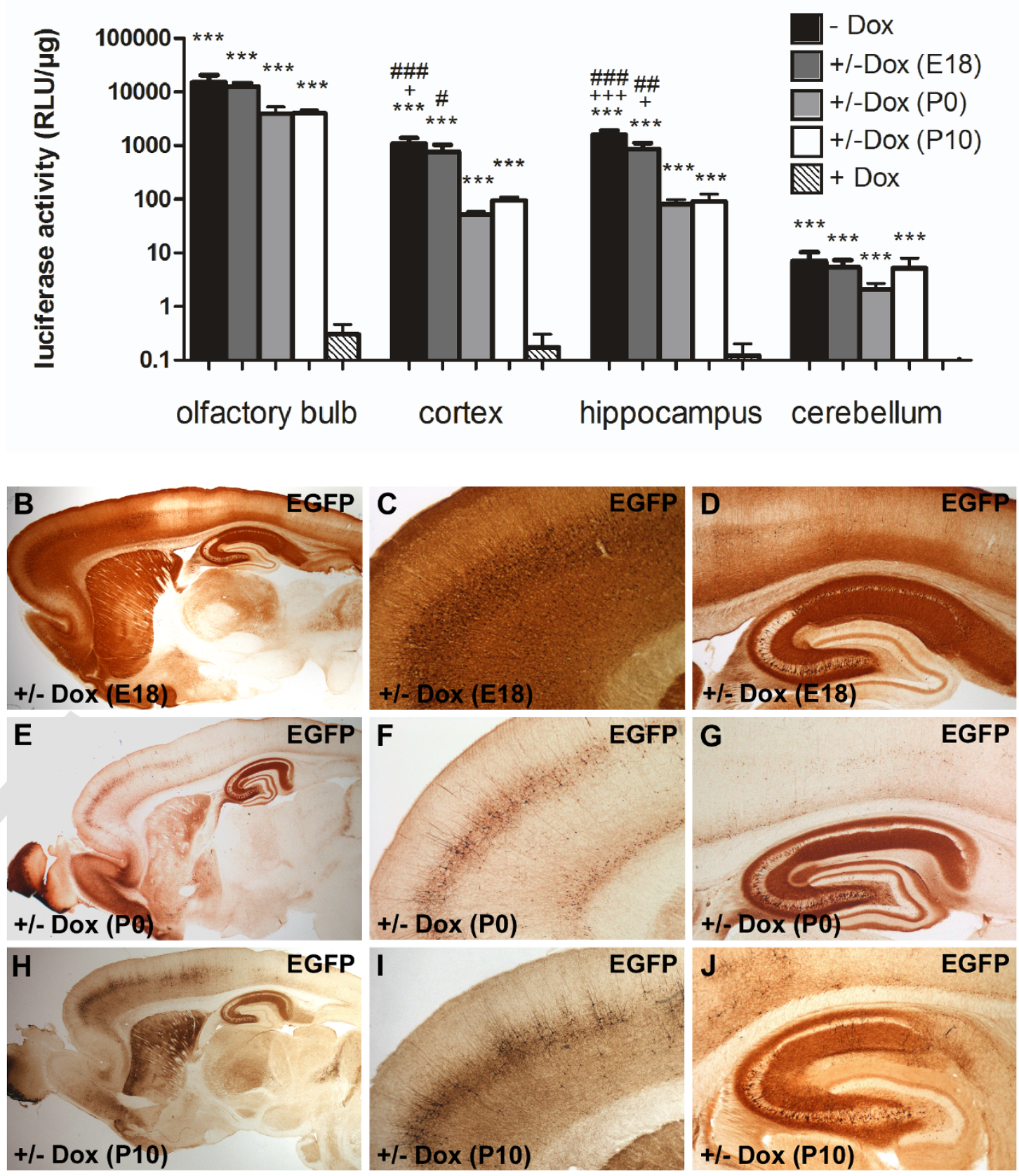

Figure 4 Activation of reporter gene expression after doxycycline withdrawal. Double transgenic CaMKIl $\alpha$-tTA/EGFP-Ptetbi-Luc rats (4.5 $\times$ 66.1) were treated with Dox during development until E18, P0 and P10, respectively (10 $\mathrm{gg} / \mathrm{mL})$. After 60 days of Dox withdrawal $( \pm D o x)$, reporter gene expression was analyzed by luciferase measurements of brain regions (A) and EGFP IHC (B-J). (A) A highly significant difference in luciferase activity was found between the different groups (olfactory bulb: $F(4,22)=143, P<0.001$; cortex: $F(4,22)=79.4, P<0.001$; hippocampus: $F(4,22)=125, P<0.001$; cerebellum: $F(4,22)=31.5, P<0.001)$. In forebrain regions (olfactory bulb, cortex, hippocampus), strong luciferase expression was induced by Dox withdrawal at E18, P0 and P10 ( \pm Dox $)$ compared with Dox-treated animals (+Dox). However, in rats which had received Dox until birth (P0) or until P10, luciferase expression did not reach the level of untreated animals (-Dox). This suggests that prolonged Dox treatment during development, in particular after birth, impairs activation of Ptet-controlled gene expression after Dox withdrawal. Data are presented as mean + standard error of the mean. Logarithmic data transformation was performed prior to statistical analysis. Characters $(*,+, \#)$ represent $P$-values obtained by one-way analysis of variance followed by Bonferroni post hoc analysis. ${ }^{*}$ represents

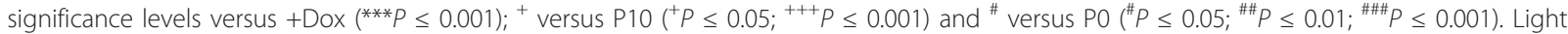
units are normalized to the protein content of the lysates. (B-J) $\mathrm{HC}$ confirms and extends the findings of the luciferase assays. Again, Doxtreated rats which had received Dox only until E18 (B-D) showed a strong forebrain-specific reporter protein expression pattern which was comparable to untreated rats (-Dox, Figure 3A-C) whereas the level of expression in all forebrain regions was significantly reduced when Dox was given until P0 (E-G) or P10 (H-J). Dox: doxycycline hydrochloride; E: embryonic day; IHC: immunohistochemistry; P: postnatal day. 
In summary, we demonstrate strong, forebrain-specific reporter gene expression in transgenic rats that can be suppressed with Dox at any desired time. The bidirectional expression module provides a useful tool for the co-regulated expression of two genes at the same time. However, prolonged Dox treatment restricts the ability to reactivate Ptet-controlled gene expression in principle forebrain neurons.

\section{Inducible gene expression in rats using the Cre/loxP system}

The CreERT2/loxP system has been widely used for tissue-specific and inducible gene ablations. Apart from this application, the CreERT2/loxP system can also be used as an alternative to the Tet system for conditional gene overexpression [34,35]. While it does not allow for reversible activation of target genes, it allows for irreversible Cre-mediated deletion or activation of loxP-flanked DNA sequences. We explored this alternative inducible expression system in rats and compared it with the Tet system. For this purpose, rat CaMKII $\alpha$-CreERT2 lines were generated and inducible recombination was functionally assessed using a newly generated Cre reporter line.

\section{Generation of CaMKII $\alpha$-CreERT2 rat lines}

Again, the same mouse CaMKII $\alpha$ promoter fragment was chosen for tissue-specific control of CreERT2 recombinase expression in forebrain neurons [5,36] (Figure 1B). Using pronuclear DNA injections, we were able to generate 14 transgenic CaMKII $\alpha$-CreERT2 founders. Offspring from all lines were initially analysed for Cre expression via IHC using a Cre antibody [37], but only eight lines showed notable Cre recombinase expression in the forebrain. We selected four CaMKII $\alpha$-CreERT2 lines (327, 396, 404 and 408) which recapitulated the forebrain-specific CaMKII $\alpha$ expression pattern [38] most adequately with abundant Cre-staining in most parts of the forebrain (Additional file 1 ), including the olfactory bulb, cortex and hippocampus. Similar to the CaMKII $\alpha$-tTA lines described above, the hippocampal dentate gyrus was largely devoid of transgenic expression. Sparse expression was also found in the striatum and thalamus.

\section{Generation of Cre reporter rats}

We generated a rat Cre reporter line pCAG-loxP.LacZ. loxP-EGFP (CAG-loxP.EGFP) to functionally characterize Cre-mediated recombination (Figure 1B). The establishment of a broadly applicable Cre reporter line critically depends on the widespread expression of its reporter genes, which ideally should not be limited to certain cell types or be influenced by position-effect variegation. Therefore, the chicken $\beta$-actin (CAG) promoter, which has been shown to confer rather ubiquitous activity in rodents in nearly all tissues [39-41], was used for the design of the reporter construct. CAG promoter sequences were placed upstream of a loxP-flanked (floxed) STOP cassette containing a nuclear localized synthetic lacZ gene and a bovine growth polyadenylation (polyA) signal to ensure transcriptional termination. This lacZ/STOP cassette was followed by EGFP as a second reporter gene. Under baseline conditions, that is without Cre-mediated recombination, the CAG promoter drives only $\beta$-galactosidase $(\beta$-gal) but not EGFP expression. Upon Cre-mediated recombination, the lacZ/STOP cassette is deleted, which activates CAG-promoter controlled expression of EGFP.

To create transgenic rat Cre reporter lines, the CAGloxP.EGFP construct was microinjected in fertilized SD oocytes, resulting in 12 Cre reporter founder rats. All founders were first assayed for baseline, non-recombined $\beta$-gal activity by $\mathrm{X}$-Gal staining of primary fibroblast cultures derived from ear biopsies (data not shown). The primary fibroblast cultures of four founder animals showed a strong nuclear X-Gal staining and those were selected for further in vivo characterization.

Tissue slices and whole organs of single transgenic CAG-loxP.EGFP rats were analysed by X-Gal staining. Line 13 showed the most abundant $\beta$-gal signal of all analysed lines (Additional file 2). Here, X-Gal staining was detected in all organs analysed, with strong and broad expression in fibroblasts, lung, kidneys, muscle, heart, spleen, pancreas, stomach and gut. Only in the liver was mosaic expression found.

Finally, we analysed CAG promoter activity in the brain. Brain sections of transgenic CAG-loxP.EGFP offspring of the four $\beta$-gal-positive CAG-loxP.EGFP Cre reporter lines were examined for $\beta$-gal expression using $\mathrm{X}-\mathrm{Gal}$ staining and IHC. Again, X-Gal staining of line 13 showed the strongest and broadest signal in the brain (Figure 5A). Dual-label fluorescent IHC with antibodies against $\beta$-gal and NeuN (Figure 5B,C) demonstrated that most NeuN-positive neurons in the brain also stained positive for $\beta$-gal (CA1: $93.4 \% \pm 2.1 \%$; cortex $91.8 \% \pm 4.7 \% ; n=3)$. By contrast, EGFP expression could not be detected, which proves that the polyA signal downstream of the $l a c Z$ gene reliably functions as a transcriptional STOP fragment, leading to tight regulation of recombination-dependent EGFP expression. Our results in rats demonstrate the broad applicability of the CAG-loxP.EGFP line 13 for functional characterization of newly generated tissue-specific rat Cre lines.

\section{Analysis of Cre-mediated gene expression in double} transgenic CaMKIl $\alpha$-CreERT2/CAG-IoxP.EGFP rats

To functionally examine the spatial and temporal pattern of CreERT2 recombinatorial activity, we crossed rats of the four CaMKII $\alpha$-CreERT2 lines (327, 396, 408 and 404) to our Cre reporter line CAG-loxP.EGFP to generate bitransgenic CaMKII $\alpha$-CreERT2/CAG-loxP.EGFP rats.

At the age of 10 weeks, double transgenic rats were intraperitoneally injected with tamoxifen $(40 \mathrm{mg} / \mathrm{kg})$ alternately once or twice per day, resulting in a total of 

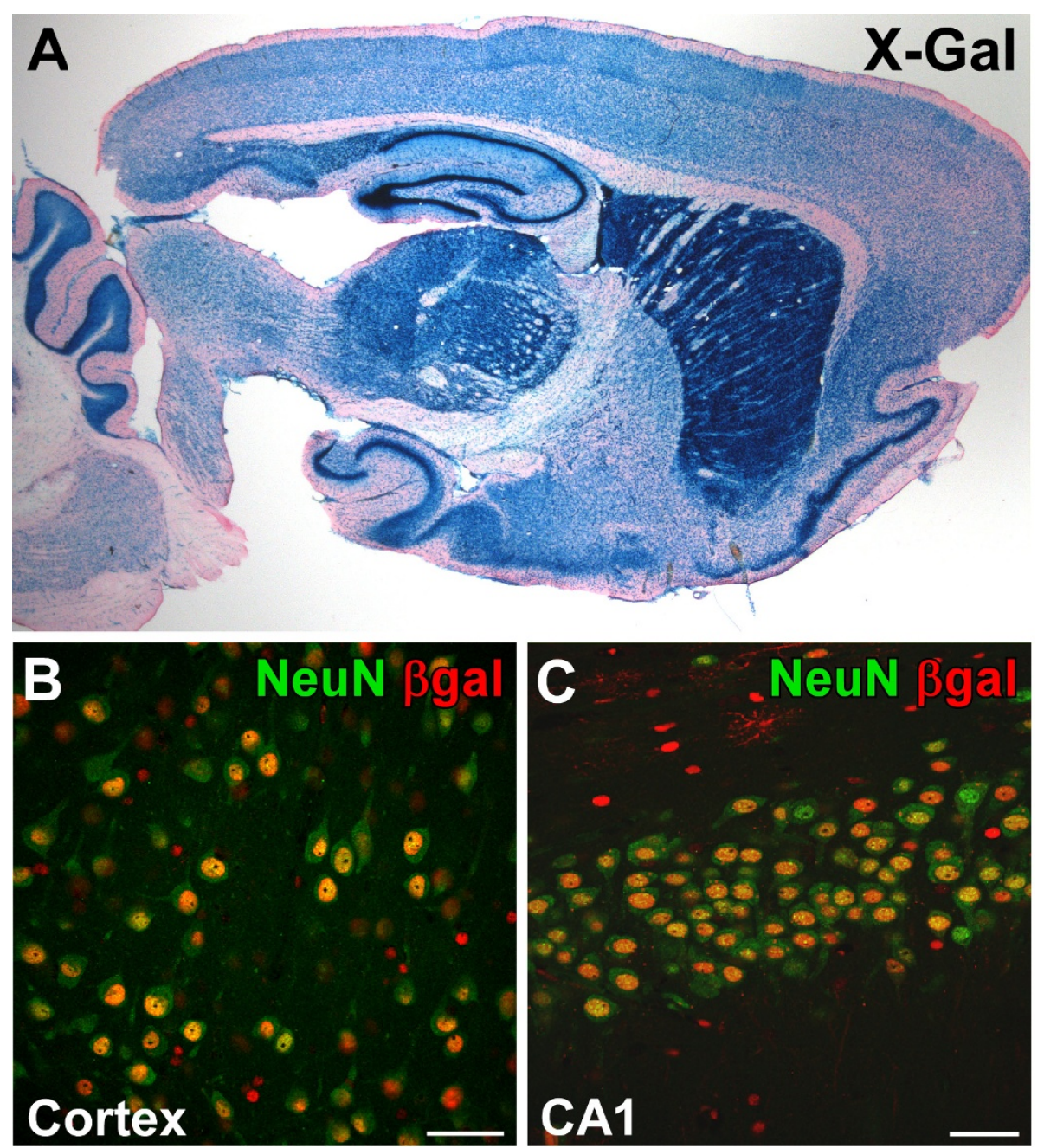

Figure $5 \beta$-galactosidase expression in the brain of the CAG-loxP.EGFP Cre reporter line 13. (A) X-Gal staining of sagittal brain sections demonstrates widespread $\beta$-galactosidase expression throughout the brain. (B,C) Neuronal $\beta$-galactosidase expression is demonstrated by colocalization of the neuronal marker NeuN and nuclear localized $\beta$-galactosidase in the cortex (B) and CA1 region of the hippocampus (C). Scale bar: $50 \mu \mathrm{m}$

seven tamoxifen injections over five consecutive days. Ten days after the last tamoxifen injection, animals were analysed with IHC for EGFP to assess forebrain-specific recombination (Figure 6). Of the four different transgenic Cre lines, CaMKII $\alpha$-CreERT2 line 327 showed the most efficient forebrain-specific recombination, that is, EGFP expression, in the hippocampus and in the cortex (Figures $6 \mathrm{~A}$ and $7 \mathrm{E}, \mathrm{H}$ ), whereas only scattered recombination was found in the striatum and thalamus (Figure 7B). Outside the forebrain, EGFP-positive cells were absent (Figure 7B). This forebrain-specific recombination pattern concurs with the recombination pattern found in CaMKII $\alpha$ CreERT2 mice, where inducible Cre activity was primarily found in the hippocampus and cortex and only low levels of CreERT2 expression were identified in the striatum and thalamus [42]. Importantly, the recombination pattern
(EGFP-positive) closely mirrored Cre expression (Figure $7 \mathrm{~A}, \mathrm{~B}, \mathrm{D}, \mathrm{E}, \mathrm{G}, \mathrm{H})$, demonstrating the excellent functionality of the reporter line to detect Cre-mediated recombination in the brain. We assume that the transgenic Cre reporter rat described herein harbours multiple, randomly integrated DNA fragments and might therefore represent an easily accessible genomic locus, ideally suited for a broad and sensitive detection of Cre-mediated recombination.

Next, we evaluated background recombination without tamoxifen treatment (Figure 7C,F,I). Sparse recombined EGFP-positive cells could be identified in various forebrain regions, for example, in the cortical somatomotor area, the postsubiculum and the piriform area. Such tamoxifenindependent recombinase activity has also been described for inducible CreERT transgenic mouse lines [43-45] and is caused by the incomplete trapping of the Cre fusion 


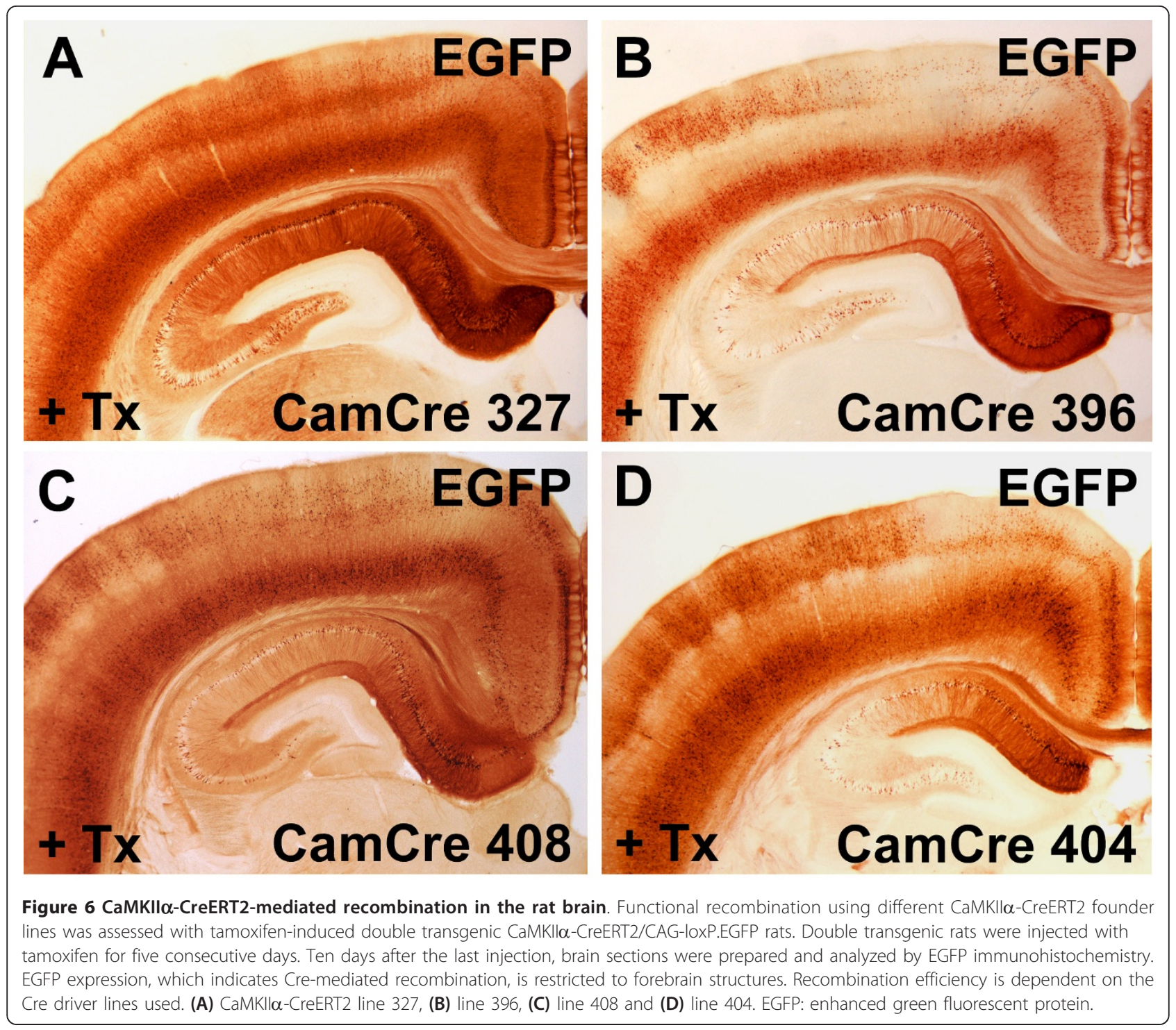

protein in the cytosol in the absence of tamoxifen. Low Cre activity in absence of the ligand was also found in CaMK-CreERT2 mouse lines [42]. Interestingly, background recombination was not observed in CAG-loxP. EGFP rats mated with less active CreERT2 driver lines, thereby confirming the observation that the ligand-independent activity of inducible Cre lines correlates with its intracellular concentration [46].

To assess cell-type-specific neuronal recombination after tamoxifen induction, double transgenic CaMKII $\alpha$ CreERT2/CAG-loxP.EGFP rats were analysed with duallabel fluorescent IHC using antibodies against EGFP and NeuN (Figure 7J-O). Confocal microscopy of hippocampal regions revealed $55.6 \%( \pm 14.2 \%, \mathrm{n}=4)$ recombined EGFP-positive/NeuN-positive neurons in CA1; 50.7\% $( \pm 4.5 \%, \mathrm{n}=3)$ in $\mathrm{CA} 3 ; 52.7 \%( \pm 11 \%, \mathrm{n}=3)$ in the hilus; and $47.4 \%( \pm 22.7 \%, \mathrm{n}=3)$ in cortical neurons.
In combination with the Cre reporter line CAG-loxP. EGFP, we demonstrate effective temporal regulation of Cre activity by tamoxifen treatment in the newly developed rat line CaMKII $\alpha$-CreERT2. In the absence of tamoxifen, only minor recombination occurs, whereas the application of tamoxifen results in widespread recombination within forebrain neurons of the hippocampus and cortex. In total, we were able to target about $50 \%$ of NeuN-positive neurons in the aforementioned regions. Similar to the Tet system, we assume that position-effect variegations in the transgenic loci are responsible for the overall variable expression $[29,30]$. We can exclude insufficient tamoxifen induction as the reason for this mosaic expression pattern, because doubling the injection time and thus tamoxifen dose did not lead to a higher recombination rate. Both the CaMKII $\alpha$-tTA and CaMKII $\alpha$ CreERT2 lines only sparsely mediate expression in the 


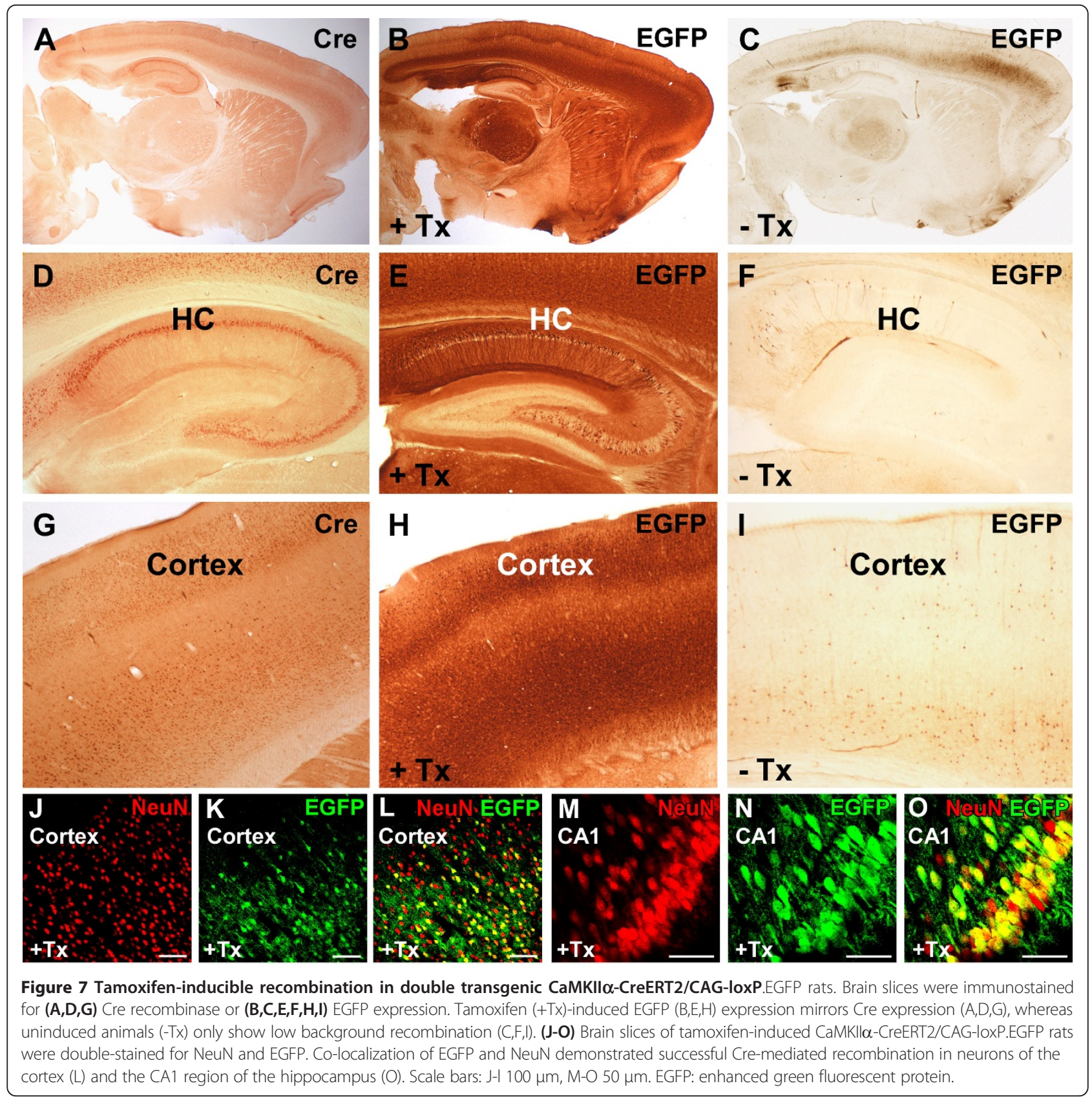

dentate gyrus or in the striatum. This common phenotype is indicative that the used mouse CaMKII $\alpha$ promoter fragment lacks regulatory sequences needed for expression specifically in this region in transgenic rats.

To date, only a limited number of Cre-expressing rat lines have been published $[47,48]$. Tissue specificity and temporal control of recombination was obtained by local injections of Cre-expressing adenoviruses $[49,50]$. However, an increasing demand for tissue-specific Creexpressing rat lines can be anticipated in the near future, as the first successful gene targeting in rat embryonic stem cells was recently published [51] and several other tools for the targeted modification of the rat genome, such as zinc finger nucleases $[11,12]$ or transcription activator-like effectors [52], are emerging. Thus, there is little doubt that conditional alleles of target genes will also become available in the rat. Another attractive application is the injection of Cre-dependent viruses to achieve optogenetic control of genetically defined cell types in rats [48]. Moreover, as depicted here with the newly developed Cre reporter line, the Cre/loxP technology can be employed for the tissue-specific overexpression of 
transgenes or alternatively for the knockdown of endogenous gene activities using polymerase II controlled small hairpin RNAs [53,54]. The presented Cre reporter line CAG-loxP.EGFP should provide a versatile tool for the characterization of newly developed Cre rat lines in both neural and non-neural tissues.

\section{Conclusions}

The laboratory rat was the earliest mammalian species domesticated for scientific research and has been used as such for over 150 years [6]. Although constitutive overexpression of genes in transgenic rats has been successfully applied to generate relevant models for gene-related diseases [55-57], only limited attempts have been made in the past to establish transgenic rat models with inducible and tissue-specific gene expression and no one has successfully addressed the brain [58]. In transgenic mice, the development of conditional strategies to control gene expression in a spatial and temporal manner has been crucial for modelling human diseases and deciphering tissue-specific gene functions [1]. With new emerging technologies, such as the presented forebrain-specific Cre or tTA driver lines, techniques in transgenic rats will close the gap with current mouse technologies. Such ratbased disease models will complement existing mouse models and the comparison of both will enable a better differentiation between rodent-specific and general mammalian phenotypes $[59,60]$.

Our experiences with both inducible systems suggest complementary applications. The Tet system should be applied for the overexpression of transgenes only during embryonic development or until a defined time point during adolescence, which then can be easily turned off by feeding Dox. By contrast, with the CreERT2-based system, a previously inactive expression module is efficiently activated any time after birth.

\section{Methods}

\section{Generation of transgenic rats EGFP-Ptetbi-luc, CaMKII $\alpha$-tTA and CaMKII $\alpha$-CreERT2 transgenic lines}

The generation of the EGFP-Ptetbi-luc tet-inducible reporter line has been described previously [22]. For the generation of forebrain-specific tTA and Cre-expressing rats, a similar strategy was applied as published by Mayford et al. [16]. In brief, the EcoRI-BamHI fragment coding for tTA2s (from pUHT61-1 [61]) and the EcoRI CreERT2 fragment (derived from pCre-ERT2 [5]), respectively, were placed downstream of the $8.5 \mathrm{~kb}$ CaMKIIa promoter sequence (pMM403). Previously, the cDNAs had been flanked by artificial introns at the 5' and 3' end (from pNN265 [62]). A SV40 polyA sequence served as the transcriptional termination signal. The CaMKII $\alpha$ pro- moter expression cassettes were separated from the vector by digestion with Sfil, purified by DNA extraction from agarose gel and microinjected at a concentration of $2 \mathrm{ng} /$ $\mu \mathrm{L}$ into fertilized SD eggs (Charles River, Sulzfeld, Germany using procedures previously described [63]. All experimental procedures were approved by the Animal Welfare Committee (Regierungspräsidium Karlsruhe) and carried out in accordance with the local Animal Welfare Act and the European Communities Council Directive of 24 November 1986 (86/609/EEC).

\section{pCAG-IoxP.EGFP Cre reporter line}

For monitoring Cre activity in transgenic rats, we designed the expression vector pCAG-loxP-lacZ-loxP. IRES-EGFP, a double-reporter construct, in which the ubiquitous cytomegalovirus enhancer/CAG promoter controls the expression of the lac $Z$ gene before and EGFP after Cre-mediated recombination. The construct was assembled using the CAG promoter of the plasmid pCA $\beta$, which was cloned upstream of the nuclear localized nlacZ gene from pMODlacZ (Invivogen, Toulouse, France) and a bovine growth hormone polyA signal, the latter being flanked by loxP sites. The expression cassette is followed by a multiple cloning site to insert a gene of interest, an internal ribosome entry site (IRES) sequence from the encephalomyocarditis virus (derived from plasmid ETL[64]) and the EGFP open reading frame (Clontech, Saint-Germain-en-Laye, France), followed by a SV40 polyA sequence. For the generation of transgenic rats harbouring the Cre double-reporter construct, a PmeI-NotI fragment was released from the pCAG-loxPlacZ-loxP.IRES-EGFP vector and microinjected at a concentration of $2 \mathrm{ng} / \mu \mathrm{L}$ into fertilized SD rat eggs. Founder rats and their offspring were analysed by Southern blotting and polymerase chain reaction of tail DNA using primers for Cre, stTA [65], synlacZ (synlacZ_for: 5'-GC TCAGGTCTCTCAATGGAG-3', syn lacZ_rev 5'-CCAG ACATCCTCCACATGTC-3') and EGFP (eGFP_for 5'TTCAAGGACGACGGCAACTACAAG-3', eGFP_rev 5'CGGCGGCGGTCACGAACTCC-3'). DNA was prepared using the DNEasy Blood \& Tissue Kit (QIAGEN, Hilden, Germany).

\section{Luciferase imaging in vivo}

Double transgenic CaMKII $\alpha$-tTA/EGFP-Ptetbi-luc rats were injected intraperitoneally with an aqueous solution of D-luciferin (150 mg D-luciferin per kilogram of body weight) and immediately placed into a light-tight chamber. Subsequently, bioluminescent imaging was performed following published procedures $[24,25]$. The emitted light was detected with the IVIS imaging system 100 (Xenogen Corporation, Alameda, California, USA) and analysis was performed using the LivingImage software (version 2.50, Xenogen Corporation). 


\section{Determination of luciferase activity in rat tissues}

Tissue samples were homogenized in passive lysis buffer (Promega, Mannheim, Germany) using the mixer-mill Tissue Lyser for 20 seconds at $30 \mathrm{~Hz}$ with $3 \mathrm{~mm}$ tungsten carbide beads. The homogenate was centrifuged for 5 minutes at $14,000 \mathrm{rpm}$ at $4^{\circ} \mathrm{C}$. The supernatants were assayed in $10 \mathrm{~mL}$ samples for luciferase activity for $1 \mathrm{sec}$ ond using the Luciferase Reporter Assay system (Promega) according to the manufacturer's instructions, in combination with Wallac Victor 2 multilabel counter (PerkinElmer, Rodgau, Germany). An aliquot of the lysates was used to determine the protein concentration by means of an improved Bradford assay (BioRad, Munich, Germany). Luciferase activities were normalized to micrograms protein $(\mathrm{RLU} / \mu \mathrm{g})$.

\section{Animal treatment (tamoxifen and doxycycline hydrochloride}

Dox was dissolved at a concentration of $1 \mathrm{mg} / \mathrm{mL}$ (+Dox experiments) and $10 \mu \mathrm{g} / \mathrm{mL}$ ( \pm Dox experiments) in tap water supplemented with $5 \%$ sucrose and supplied to the animals ad libitum. Tamoxifen (Sigma-Aldrich, Munich, Germany, T5648) was dissolved in a pH neutral mediumchain triglyceride (Neutralöl, Euro OTC Pharma, Bönen, Germany) at a final concentration of $20 \mathrm{mg} / \mathrm{mL}$. Two- to three-month-old rats were injected intraperitoneally with $40 \mathrm{mg} / \mathrm{kg}$ body weight of tamoxifen alternating once or twice per day for five consecutive days (starting with a single injection on day 1). Experimental animals for immunohistochemistry and Cre reporter analysis were analysed 10 days after the last injection.

\section{Immunohistochemistry and $\boldsymbol{\beta}$-galactosidase staining}

$\beta$-gal activity in transgenic rats was characterized by $\mathrm{X}$-Gal staining and IHC. Dissected brains were postfixed with $4 \%$ paraformaldehyde at $4{ }^{\circ} \mathrm{C}$ for 24 to 48 hours. Brain sections $(50 \mu \mathrm{m})$ were prepared using a vibratome (Leica, Wetzlar, Germany). Floating sections were processed for IHC using the VECTASTAIN ABC system (Vector Laboratories, Burlingame, California, USA) and diaminobenzidine (Sigma-Aldrich) in combination with polyclonal rabbit anti-Cre (a generous gift from $G$. Schütz, DKFZ, 1:3000) and polyclonal rabbit anti-GFP (Invitrogen, Darmstadt, Germany 1:1000) antibodies.

Double fluorescence IHC was performed to visualize $\beta$-gal and GFP expression in NeuN-positive neurons using the primary antibodies chicken anti- $\beta$-gal (Abcam, Cambridge, UK, 1:10,000), mouse monoclonal anti-NeuN (Millipore, Schwalbach, Germany 1:4,000) and polyclonal rabbit anti-GFP (Invitrogen, 1:1,000). Brain sections were permeabilized with Triton X-100 (0.1\%) for 30 minutes in $1 \times \mathrm{PBS}$ at $4^{\circ} \mathrm{C}$, washed with $1 \times \mathrm{PBS}$ (three times) and blocked with $10 \%$ donkey serum in $1 \times$ PBS for 1 hour.
The primary antibodies were added to the blocking solution and incubated at $4^{\circ} \mathrm{C}$ overnight on an orbital shaker. Next day, following three washings with PBS, the sections were incubated in blocking solution containing the secondary antibodies for 1 hour at room temperature. After final washes with $1 \times$ PBS, sections were mounted in Dako fluorescence mounting medium. Secondary antibodies were AF488 donkey $\alpha$-mouse (Invitrogen, 1:200) and Cy3 donkey $\alpha$-chicken $(1: 1,000)$. Sagittal vibratome sections were examined using confocal laser-scanning microscopes (Nikon C1Si-CLEM, Nikon Imaging Center, BioQuant, Heidelberg, Germany and Leica TCS SP5, Central Institute of Mental Health, Mannheim, Germany).

For $\beta$-gal staining, similar brain sections were incubated with X-Gal staining solution (5 mM EGTA, $2 \mathrm{mM} \mathrm{MgCl}_{2}$, $0.01 \% \mathrm{C}_{24} \mathrm{H}_{39} \mathrm{O}_{4} \mathrm{Na}, 0.02 \% \mathrm{NP}-40,10 \mathrm{mM} \mathrm{K}_{3}\left(\mathrm{Fe}(\mathrm{CN})_{6}\right), 10$ $\mathrm{mM} \mathrm{K}_{4}\left(\mathrm{Fe}(\mathrm{CN})_{6}\right)$ and $0.5 \mathrm{mg} / \mathrm{mL} \mathrm{X}-\mathrm{Gal}$ in $\left.1 \times \mathrm{PBS}\right)$ at $37^{\circ}$ $\mathrm{C}$ for several hours. Finally, the stained slices were counterstained with nuclear fast red (Sigma) and mounted with Eukitt (O. Kindler, Freiburg, Germany).

\section{Ear fibroblast culture and transfection}

Ear fibroblast cultures were prepared from ear biopsies of founder animals using a protocol previously described [66]. Depending on the transgene, the cells were directly examined either by X-Gal staining or transfected with tTA expression plasmids using lipofectamine-2000 (Invitrogen) according to the manufacturer's protocol.

\section{Statistical analysis}

Statistical analyses of luciferase data were performed using either t-test or univariate analysis of variance (ANOVA), followed by Bonferroni post hoc analysis. Respective $F$-and $P$-values were calculated using GraphPad Prism 5.0. All data are presented as mean \pm standard error of the mean (SEM). A $P$-value $\leq 0.05$ was considered statistically significant. Sagittal slices of adult pCAG-loxP.EGFP, CaMKII $\alpha$ tTA/EGFP-Ptetbi-luc and CaMKII $\alpha$-CreERT2/CAG-loxP. EGFP rats were processed with dual-label fluorescent IHC detecting EGFP and NeuN. Images were acquired using a confocal laser-scanning microscope. The ratio of GFPpositive/NeuN-positive neurons to all NeuN-positive neurons was calculated separately for cortex and hippocampal regions (CA1, CA3 and hilus). Mean and SEM were calculated from at least three rats per group.

\section{Commitment to distribute transgenic rat lines}

All transgenic rat lines generated in this project will be made available upon request to scientists at academic institutions for non-commercial research or deposited into a repository/stock centre, making them available to the broader research community. We will process requests in an appropriate timely fashion and in the order of request 
received, provided the recipient will bear all costs for the shipment and sign our institutional Material Transfer Agreement. For scientists requesting rats harbouring components of the Tet system, the Notice and Acknowledgement Agreement (N\&A) of 'TET Systems' available at http://www.tetsystems.com/ip-licensing/licensing/not-forprofit-research needs to be completed before these rats can be transferred to recipients.

\section{Additional material}

\section{Additional file 1: CreERT2 protein expression in the brain of} transgenic CaMKII $\alpha$-CreERT2 rats. CaMKIl $\alpha$-CreERT2 rats were injected twice within 12 hours with tamoxifen for nuclear localization of the Cre recombinase. Three hours after the second injection, animals were prepared for analysis. Brain sections were immunostained using a Cre antibody. The most prominent Cre immunoreactivity was found in hippocampal pyramidal neurons $(B, C, E, G)$ and in cortical structures. CaMKIll-CreERT2 line 327 (A,B); line 396 (C,D); line 408 (E,F) and line 404 $(\mathrm{G}, \mathrm{H})$.

Additional file 2: Constitutive $\beta$-galactosidase expression in transgenic pCAG-loxP.EGFP Cre reporter rats. Macroscopic appearance of X-Gal-stained tissues revealed strong b-galactosidase expression in the lung, kidney, muscle, heart, spleen and gastrointestinal tract including appendix and pancreas.

\section{Abbreviations}

ANOVA: analysis of variance; $\beta$-gal: $\beta$-galactosidase; CAG: chicken $\beta$-actin; Dox: doxycycline hydrochloride; E: embryonic day; EGFP: enhanced green fluorescent protein; GFP: green fluorescent protein; $\mathrm{HC}$

immunohistochemistry; P: postnatal day; PBS: phosphate-buffered saline; SEM: standard error of the mean; RLU: relative light units; tet: tetracycline; tTA: tetracycline-dependent transactivator.

\section{Acknowledgements}

We thank the animal care team of the Central Institute of Mental Health for assistance in animal handling. We also thank Günther Schütz for providing the Cre antibody and Pierre Chambon for the CreERT2 plasmid. This work was funded by the following grants: EU HEALTH-F2-2007-201714 DEVANX, the German Ministry of Education and Research (BMBF, 01GQ1003B) and BMBF NGFN-Plus grant (01GS0851) to DB.

\section{Author details}

'Department of Molecular Biology, Central Institute of Mental Health and Heidelberg University, Medical Faculty Mannheim, J5, 68159 Mannheim, Germany. ${ }^{2}$ Department of Addictive Behavior and Addiction Medicine, Central Institute of Mental Health, Heidelberg University, J5, 68159 Mannheim, Germany. ${ }^{3}$ German Cancer Research Center (DKFZ), Molecular Immunology, Im Neuenheimer Feld 580, 69120 Heidelberg, Germany. ${ }^{4}$ Zentrum für Molekulare Biologie Heidelberg, Im Neuenheimer Feld 282, 69120 Heidelberg, Germany.

\section{Authors' contributions}

KS conceived the study, generated transgenic DNA constructs, collected and analysed experimental data and drafted the manuscript. TW participated in the design of the study, carried out the statistical analysis and drafted the manuscript. AF performed DNA microinjections and genotyping of the transgenic animals. LW functionally analysed the expression pattern of the CaMKIla-tTA and CaMKIla-CreERT2 founder lines by X-Gal stainings, luciferase measurements and $\mathrm{IHC}$. BP helped in the cloning of transgenic constructs. DD performed in vivo luciferase imaging experiments. $\mathrm{HB}$ and DB conceived the study and helped to draft the manuscript. All authors read and approved the final manuscript.

\section{Competing interests}

The authors declare that they have no competing interests.

Received: 19 June 2012 Accepted: 3 September 2012

Published: 3 September 2012

\section{References}

1. Lewandoski M: Conditional control of gene expression in the mouse. Nat Rev Genet 2001, 2(10):743-755.

2. van der Weyden L, White JK, Adams DJ, Logan DW: The mouse genetics toolkit: revealing function and mechanism. Genome Biol 2011, 12(6):224.

3. Sauer B, Henderson N: Site-specific DNA recombination in mammalian cells by the Cre recombinase of bacteriophage P1. Proc Nat Acad Sci USA 1988, 85(14):5166-5170

4. Gossen M, Bujard $\mathrm{H}$ : Tight control of gene expression in mammalian cells by tetracycline-responsive promoters. Proc Nat Acad Sci USA 1992, 89(12):5547-5551.

5. Feil R, Wagner J, Metzger D, Chambon P: Regulation of Cre recombinase activity by mutated estrogen receptor ligand-binding domains. Biochem Biophys Res Commun 1997, 237(3):752-757

6. Jacob HJ: Functional genomics and rat models. Genome Res 1999, 9(11):1013-1016

7. Abbott A: Laboratory animals: the Renaissance rat. Nature 2004, 428(6982):464-466.

8. Aitman TJ, Critser JK, Cuppen E, Dominiczak A, Fernandez-Suarez XM, Flint J, Gauguier D, Geurts AM, Gould M, Harris PC, Holmdahl R, Hubner N, Izsvák Z, Jacob HJ, Kuramoto T, Kwitek AE, Marrone A, Mashimo T, Moreno C, Mullins J, Mullins L, Olsson T, Pravenec M, Riley L, Saar K, Serikawa T, Shull JD, Szpirer C, Twigger SN, Voigt B, Worley K: Progress and prospects in rat genetics: a community view. Nat Genet 2008, 40(5):516-522.

9. Costantini LC, Bakowska JC, Breakefield XO, Isacson O: Gene therapy in the CNS. Gene Ther 2000, 7(2):93-109.

10. van Boxtel $R$, Cuppen E: Rat traps: filling the toolbox for manipulating the rat genome. Genome Biol 2010, 11(9):217.

11. Geurts AM, Cost GJ, Freyvert Y, Zeitler B, Miller JC, Choi VM, Jenkins SS, Wood A, Cui X, Meng X, Vincent A, Lam S, Michalkiewicz M, Schilling R, Foeckler J, Kalloway S, Weiler H, Ménoret S, Anegon I, Davis GD, Zhang L, Rebar EJ, Gregory PD, Urnov FD, Jacob HJ, Buelow R: Knockout rats via embryo microinjection of zinc-finger nucleases. Science 2009, 325(5939):433

12. Cui $X$, Ji D, Fisher DA, Wu Y, Briner DM, Weinstein EJ: Targeted integration in rat and mouse embryos with zinc-finger nucleases. Nature Biotechnol 2011, 29(1):64-67.

13. Zhang $F$, et al: Efficient construction of sequence-specific TAL effectors for modulating mammalian transcription. Nature Biotechnol 2011, 29(2):149-153.

14. Buehr M, Meek S, Blair K, Yang J, Ure J, Silva J, McLay R, Hall J, Ying QL, Smith $A$ : Capture of authentic embryonic stem cells from rat blastocysts. Cell 2008, 135(7):1287-1298

15. Li P, Tong C, Mehrian-Shai R, Jia L, Wu N, Yan Y, Maxson RE, Schulze EN, Song $\mathrm{H}$, Hsieh $\mathrm{CL}$, Pera MF, Ying QL: Germline competent embryonic stem cells derived from rat blastocysts. Cell 2008, 135(7):1299-1310.

16. Mayford M, Bach ME, Huang YY, Wang L, Hawkins RD, Kandel ER: Control of memory formation through regulated expression of a CaMKII transgene. Science 1996, 274(5293):1678-1683

17. Schönig K, Bujard H, Gossen M: The power of reversibility regulating gene activities via tetracycline-controlled transcription. Methods Enzymol 2010, 477:429-453.

18. Chen J, Kelz MB, Zeng G, Sakai N, Steffen C, Shockett PE, Picciotto MR, Duman RS, Nestler EJ: Transgenic animals with inducible, targeted gene expression in brain. Mol Pharmacol 1998, 54(3):495-503.

19. Tichelaar JW, Lu W, Whitsett JA: Conditional expression of fibroblast growth factor-7 in the developing and mature lung. J Biol Chem 2000, 275(16):11858-11864.

20. Thomas MK, Devon ON, Lee JH, Peter A, Schlosser DA, Tenser MS, Habener JF: Development of diabetes mellitus in aging transgenic mice following suppression of pancreatic homeoprotein IDX-1. J Clin Invest 2001, 108(2):319-329 
21. Baron U, Freundlieb S, Gossen M, Bujard H: Co-regulation of two gene activities by tetracycline via a bidirectional promoter. Nucleic Acids Res 1995, 23(17):3605-3606.

22. Schönig K, Kentner D, Gossen M, Baldinger T, Miao J, Welzel K, Vente A, Bartsch D, Bujard H: Development of a BAC vector for integrationindependent and tight regulation of transgenes in rodents via the Tet system. Transgenic Res 2011, 20(3):709-720.

23. Boross P, Breukel C, van Loo PF, van der Kaa J, Claassens JW, Bujard H, Schönig K, Verbeek JS: Highly B lymphocyte-specific tamoxifen inducible transgene expression of CreER T2 by using the LC-1 locus BAC vector. Genesis 2009, 47(11):729-735.

24. Contag $\mathrm{CH}$, Bachmann $\mathrm{MH}$ : Advances in in vivo bioluminescence imaging of gene expression. Annu Rev Biomed Eng 2002, 4:235-260.

25. Hasan MT, Schonig K, Berger S, Graewe W, Bujard H: Long-term, noninvasive imaging of regulated gene expression in living mice. Genesis 2001, 29(3):116-122.

26. Krestel HE, Shimshek DR, Jensen V, Nevian T, Kim J, Geng Y, Bast T, Depaulis A, Schonig K, Schwenk F, Bujard H, Hvalby $\varnothing$, Sprengel R, Seeburg PH: A genetic switch for epilepsy in adult mice. J Neurosci 2004, 24(46):10568-10578.

27. Lindeberg J, Mattsson R, Ebendal T: Timing the doxycycline yields different patterns of genomic recombination in brain neurons with a new inducible Cre transgene. J Neurosci Res 2002, 68(2):248-253.

28. Ghavami A, Stark KL, Jareb M, Ramboz S, Ségu L, Hen R: Differential addressing of 5-HT1A and 5-HT1B receptors in epithelial cells and neurons. J Cell Sci 1999, 112(Pt 6):967-976.

29. Dobie K, Mehtali M, McClenaghan M, Lathe R: Variegated gene expression in mice. Trends Genet 1997, 13(4):127-130.

30. Robertson G, Garrick D, Wu W, Kearns M, Martin D, Whitelaw E: Positiondependent variegation of globin transgene expression in mice. Proc Nat Acad Sci USA 1995, 92(12):5371-5375.

31. Krestel HE, Mayford M, Seeburg PH, Sprengel R: A GFP-equipped bidirectional expression module well suited for monitoring tetracyclineregulated gene expression in mouse. Nucleic Acids Res 2001, 29(7):E39.

32. Bejar R, Yasuda R, Krugers H, Hood K, Mayford M: Transgenic calmodulindependent protein kinase II activation: dose-dependent effects on synaptic plasticity, learning, and memory. J Neurosci 2002, 22(13):5719-5726.

33. Zhu P, Aller MI, Baron U, Cambridge S, Bausen M, Herb J, Sawinski J, Cetin A, Osten P, Nelson ML, Kügler S, Seeburg PH, Sprengel R, Hasan MT: Silencing and un-silencing of tetracycline-controlled genes in neurons. Plos One 2007, 2(6):e533.

34. Ryding AD, Sharp MG, Mullins JJ: Conditional transgenic technologies. $J$ Endocrinol 2001, 171(1):1-14.

35. Nagy A: Cre recombinase: the universal reagent for genome tailoring. Genesis 2000, 26(2):99-109.

36. Indra AK, Warot X, Brocard J, Bornert JM, Xiao JH, Chambon P, Metzger D: Temporally-controlled site-specific mutagenesis in the basal layer of the epidermis: comparison of the recombinase activity of the tamoxifeninducible Cre-ER(T) and Cre-ER(T2) recombinases. Nucleic Acids Res 1999, 27(22):4324-4327.

37. Kellendonk C, Tronche F, Casanova E, Anlag K, Opherk C, Schütz G: Inducible site-specific recombination in the brain. J Mol Biol 1999, 285(1):175-182.

38. Minichiello L, Korte M, Wolfer D, Kühn R, Unsicker K, Cestari V, Rossi-Arnaud C, Lipp HP, Bonhoeffer T, Klein R: Essential role for TrkB receptors in hippocampus-mediated learning. Neuron 1999, 24(2):401-414.

39. Murakami T, Kobayashi E: Color-engineered rats and luminescent LacZ imaging: a new platform to visualize biological processes. J Biomed Opt 2005, 10(4):41204

40. Okabe M, Ikawa M, Kominami K, Nakanishi T, Nishimune Y: 'Green mice' as a source of ubiquitous green cells. FEBS letters 1997, 407(3):313-319.

41. Hakamata Y, Tahara K, Uchida H, Sakuma Y, Nakamura M, Kume A, Murakami T, Takahashi M, Takahashi R, Hirabayashi M, Ueda M, Miyoshi I, Kasai N, Kobayashi E: Green fluorescent protein-transgenic rat: a tool for organ transplantation research. Biochem Biophys Res Commun 2001, 286(4):779-785.

42. Erdmann G, Schutz G, Berger S: Inducible gene inactivation in neurons of the adult mouse forebrain. BMC Neurosci 2007, 8:63,

43. Kemp R, Ireland H, Clayton E, Houghton C, Howard L, Winton DJ: Elimination of background recombination: somatic induction of Cre by combined transcriptional regulation and hormone binding affinity. Nucleic Acids Rese 2004, 32(11):e92.
44. Hameyer D, Loonstra A, Eshkind L, Schmitt S, Antunes C, Groen A, Bindels E, Jonkers J, Krimpenfort P, Meuwissen R, Rijswijk L, Bex A, Berns A, Bockamp E: Toxicity of ligand-dependent Cre recombinases and generation of a conditional Cre deleter mouse allowing mosaic recombination in peripheral tissues. Physiol Genomics 2007, 31(1):32-41.

45. Liu Y, Suckale J, Masjkur J, Magro MG, Steffen A, Anastassiadis K, Solimena M: Tamoxifen-independent recombination in the RIP-CreER mouse. Plos One 2010, 5(10):e13533.

46. Buelow B, Scharenberg AM: Characterization of parameters required for effective use of tamoxifen-regulated recombination. PloS One 2008, 3(9): e3264.

47. Weber T, Schonig K, Tews B, Bartsch D: Inducible gene manipulations in brain serotonergic neurons of transgenic rats. PloS One 2011, 6(11): e28283.

48. Witten IB, et al: Recombinase-driver rat lines: tools, techniques, and optogenetic application to dopamine-mediated reinforcement. Neuron 2011, 72(5):721-733.

49. Sato $Y$, Endo H, Ajiki T, Hakamata $Y$, Okada T, Murakami T, Kobayashi E: Establishment of Cre/LoxP recombination system in transgenic rats. Biochem Biophys Res Commun 2004, 319(4):1197-1202.

50. Ueda S, Fukamachi K, Matsuoka Y, Takasuka N, Takeshita F, Naito A, ligo M, Alexander DB, Moore MA, Saito I, Ochiya T, Tsuda H: Ductal origin of pancreatic adenocarcinomas induced by conditional activation of a human Ha-ras oncogene in rat pancreas. Carcinogenesis 2006, 27(12):2497-2510.

51. Tong C, Li P, Wu NL, Yan Y, Ying QL: Production of p53 gene knockout rats by homologous recombination in embryonic stem cells. Nature 2010, 467(7312):211-213

52. Tesson L, Usal C, Ménoret S, Leung E, Niles BJ, Remy S, Santiago Y, Vincent Al, Meng X, Zhang L, Gregory PD, Anegon I, Cost GJ: Knockout rats generated by embryo microinjection of TALENs. Nat Biotechnol 2011, 29(8):695-696.

53. Berger SM, Pesold B, Reber S, Schönig K, Berger AJ, Weidenfeld I, Miao J, Berger MR, Gruss OJ, Bartsch D: Quantitative analysis of conditional gene inactivation using rationally designed, tetracycline-controlled miRNAs. Nucleic Acids Res 2010, 38(17):e168.

54. Dickins RA, McJunkin K, Hernando E, Premsrirut PK, Krizhanovsky V, Burgess DJ, Kim SY, Cordon-Cardo C, Zender L, Hannon GJ, Lowe SW: Tissue-specific and reversible RNA interference in transgenic mice. Nat Genet 2007, 39(7):914-921.

55. Mullins JJ, Peters J, Ganten D: Fulminant hypertension in transgenic rats harbouring the mouse Ren-2 gene. Nature 1990, 344(6266):541-544.

56. Hammer RE, Maika SD, Richardson JA, Tang JP, Taurog JD: Spontaneous inflammatory disease in transgenic rats expressing HLA-B27 and human beta 2m: an animal model of HLA-B27-associated human disorders. Cell 1990, 63(5):1099-1112.

57. Herrera VL, Makrides SC, Xie HX, Adari H, Krauss RM, Ryan US, Ruiz-Opazo N: Spontaneous combined hyperlipidemia, coronary heart disease and decreased survival in Dahl salt-sensitive hypertensive rats transgenic for human cholesteryl ester transfer protein. Nat Med 1999, 5(12):1383-1389.

58. Konopka W, Duniec K, Klejman A, Wawrzyniak M, Owczarek D, Gawrys L, Maleszewski M, Mallet J, Kaczmarek L: Tet system in the brain: transgenic rats and lentiviral vectors approach. Genesis 2009, 47(4):274-280.

59. Gao X, Zhang P: Transgenic RNA interference in mice. Physiology (Bethesda) 2007, 22:161-166.

60. Zhou H, Huang C, Yang M, Landel CP, Xia PY, Liu YJ, Xia XG: Developing tTA transgenic rats for inducible and reversible gene expression. Int J Bio Sci 2009, 5(2):171-181.

61. Urlinger S, Baron U, Thellmann M, Hasan MT, Bujard H, Hillen W: Exploring the sequence space for tetracycline-dependent transcriptional activators: novel mutations yield expanded range and sensitivity. Proc Nat Acad Sci USA 2000, 97(14):7963-7968.

62. Choi T, Huang M, Gorman C, Jaenisch R: A generic intron increases gene expression in transgenic mice. Mol Cell Biol 1991, 11(6):3070-3074.

63. Hogan H, Beddington R, Constantini F, Lacy E: Manipulating the Mouse Embryo: A Laboratory Manual. Cold Spring Harbor, NY: Cold Spring Harbor Laboratory Press; 21994

64. Mombaerts P, Wang F, Dulac C, Chao SK, Nemes A, Mendelsohn M, Edmondson J, Axel R: Visualizing an olfactory sensory map. Cell 1996, 87(4):675-686. 
65. Schönig K, Schwenk F, Rajewsky K, Bujard H: Stringent doxycycline dependent control of CRE recombinase in vivo. Nucleic Acids Res 30(23):e134

66. Schönig K, Bujard H: Generating conditional mouse mutants via tetracycline-controlled gene expression. Methods Mol Biol 2003, 209:69-104.

doi:10.1186/1741-7007-10-77

Cite this article as: Schönig et al: Conditional gene expression systems

in the transgenic rat brain. BMC Biology 2012 10:77.

Submit your next manuscript to BioMed Central and take full advantage of:

- Convenient online submission

- Thorough peer review

- No space constraints or color figure charges

- Immediate publication on acceptance

- Inclusion in PubMed, CAS, Scopus and Google Scholar

- Research which is freely available for redistribution

Submit your manuscript at www.biomedcentral.com/submit 